\title{
IMPLEMENTASI DESIGN THINKING PADA PROYEK DESAIN SOSIAL: PERANCANGAN BUKU ANYAMAN SEBAGAI STIMULUS UNTUK PENGRAJIN ANYAMAN ROTAN DI DESA JAMBE
}

\author{
Devanny Gumulya ${ }^{1}$, Calvin², I Gede Agastya ${ }^{3}$, Kristian Harijadi ${ }^{3}$, Jordan Surjadi ${ }^{4}$ \\ ${ }^{1-4}$ Universitas Pelita Harapan \\ devanny.gumulya@uph.edu
}

\begin{abstract}
Abstrak
Pemikiran desain (design thinking) sudah banyak diaplikasikan pada proyek desain dengan berbagai konteks salah satunya di dalam proyek desain sosial. Paper ini mencoba menstudi bagaimana aplikasi pemikiran desain diimplementasikan dalam perancangan proyek desain sosial bagi pengrajin anyaman rotan di Desa Jambe. Proses pemikiran desain dimulai dari proses empati, definisi masalah, pencarian ide, pembuatan purwarupa dan uji coba. Dari proses empati ditemukan bahwa pengrajin mengalami kendala dalam pengembangan desain, sehingga produk yang dijual tidak berkembang, kalah bersaing, sehingga yang bisa ditawarkan adalah harga yang ekonomis bersaing dengan pengrajin rotan Cirebon yang bisa menawarkan harga yang lebih murah. Oleh karena itu dalam proyek sosial ini dibuat buku mengenai teknik, warna, serta finishing rotan yang sudah dimiliki pengrajin dan bagaimana mengembangkannya. Tujuannya adalah agar pengrajin dapat terinspirasi menemukan bentuk dan pola anyaman yang baru dengan menggunakan buku ini. Akhir dari kegiatan ini, tim sudah mengalami kendala pandemi Covid 19, sehingga buku diujikan melalui video conference kepada komunitas pengrajin rotan Jambe.
\end{abstract}

Kata Kunci : pemikiran desain, desain sosial, desain produk, anyaman rotan

\section{PENDAHULUAN}

Sejak tahun 1985, profesi desain produk berkembang tidak lagi hanya memikirkan bagaimana mendesain produk yang dapat meningkatkan pendapatan perusahaan dan berguna pagi pengguna, tapi dapat berpartisipasi pada keberlangsungan lingkungan dan kesejahteraan sosial, dan munculah istilah desain sosial (Papanek 1985; Whiteley 1993; Ramirez 2011).

Desain sosial adalah desain yang berfungsi untuk menyelesaikan masalah sosial yang dihadapi suatu komunitas (Margolin, 2002). Menurut Amstrong (2014), desain sosial adalah perancangan yang bertujuan untuk kepentingan kolektif dan bermisi sosial bukan untuk tujuan komersil atau untuk kepentingan golongan tertentu. Proyek desain sosial melibatkan banyak pihak dan ahli untuk saling berkolaborasi dan mengembangkan visi sosial bersama diseluruh rangkaian proses pemikiran desain mulai dari identifikasi masalah, pembuatan purwarupa hingga proses evaluasi (Jégou and Manzini 2008).

Salah satu contoh proyek desain sosial dengan metode co-design (Amatullo, 2018) adalah COANIQUEM: Safe Niños: Co-creating Innovative Healing Environments for Children yang adalah suatu proyek sosial dari departemen DesignMatters di Artcenter College of Design, Pasadena, AS yang berkolaborasi dengan COANIQUEM, sebuah organisasi nirlaba yang memberikan perawatan kepada anak-anak dengan luka bakar di fasilitas

$$
\text { Teknologi Tepat Guna }
$$


mereka di Santiago, Chile. Tujuan kerjasama ini adalah untuk membuat sebuah ruang atau wadah dimana anak-anak dan orang tua dapat menjalani pemulihan dengan lancar dan nyaman.

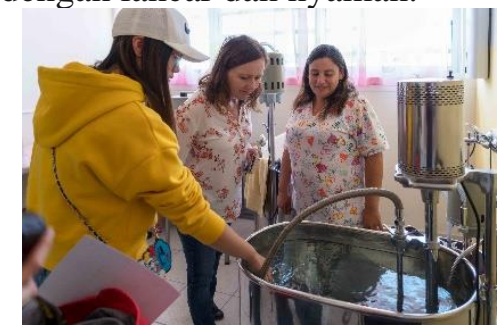

Gambar 1. 1 Riset Observasi yang Dilakukan di Fasilitas Pemulihan

[Sumber:https://designmattersatartcenter.org/proj/coanique

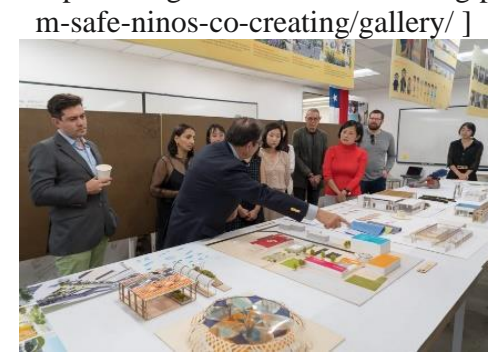

Gambar 1. 2 Kolaborasi pihak COANIQUEM Dengan Tim Mahasiswa

[Sumber:

https://designmattersatartcenter.org/proj/coaniquem-safe-ninosco-creating/gallery/ ]

Hasil dari proyek ini adalah kumpulan produk, desain arsitektur, serta rancangan desain komunikasi visual seperti sign system, buku cerita yang bekerja secara bersinergri untuk merehabilitasi pasien serta memberikan informasi untuk menambah wawasan masyarakat. solusi yang dihasilkan: Antafagasta Masterplan adalah sebuah rencana tempat pemulihan pasien di mana pengaturannya melibatkan interaksi keluarga pasien dan pasien dengan penduduk lokal via area komunal. Penggunaan ruang dan fasilitas bermain memberikan pilihan bagi pasien untuk bermain dulu sebelum melanjutkan pemulihan. Berikut merupakan fasilitas yang tersedia:

1) Gereja yang ditempatkan di tengah Masterplan. Gereja ini menjadi pusat spiritual di Desa Coaniquem

2) Area taman hijau yang terletak di seberang gereja dan fasilitas lain seperti restoran, café, taman, tempat bermain, dan ruang hijau yang bisa dinikmati oleh semua orang (Garden of Life at Antafagasta)

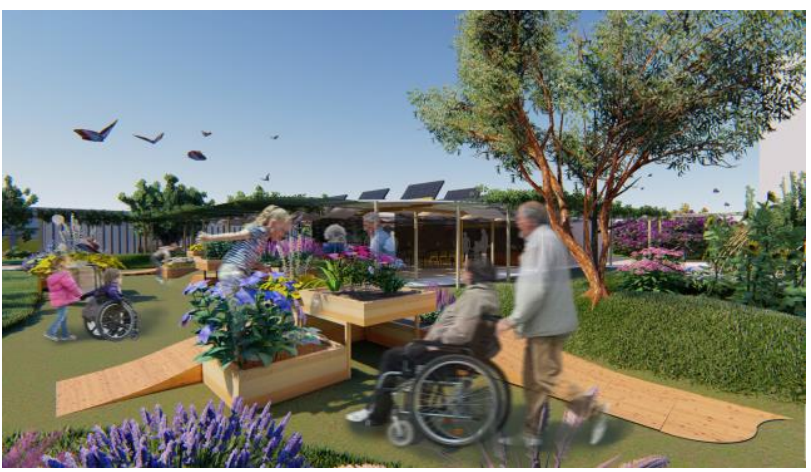

Gambar 1. 3 Taman Garden of Life di Antafagasta

[Sumber:https://designmattersatartcenter.org/proj/coanique m-safe-ninos-co-creating/gallery/ ]

3) Jalan akses dan tempat parkir terletak di luar desa sehingga bisa memudahkan pejalan dan bebas dari mobil.

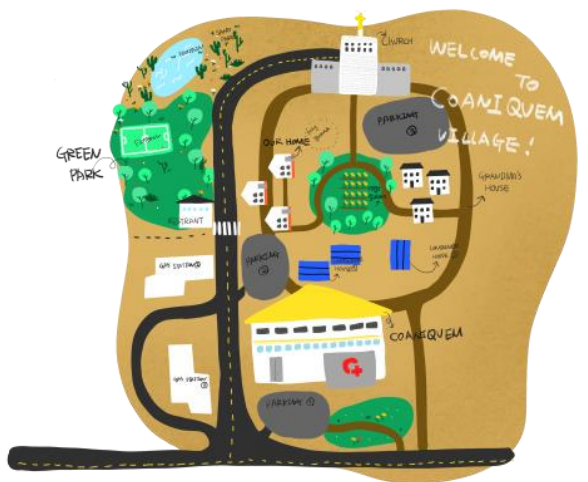

Gambar 1. 4 Masterplan Antafagasta

[Sumber:https://designmattersatartcenter.org/proj/coanique m-safe-ninos-co-creating/gallery/ ]

4) Ruang bernarasi legenda cerita lokal berjudul "Healing Tree (pohon kesembuhan)" dengan tokoh nama - nama penduduk, geografi dan fauna lokal. Pada dasarnya ruang bercerita bagaimana perjuangan anak - anak untuk mencari kesembuhan dengan berpetualang mencari harta karun. Misalnya rute "healing treasure" dimana pada jalur ini tokoh cerita berusaha mencari harta karun untuk dibawah pulang yang akan menyuburkan tanah dan air untuk pohon kesembuhan 


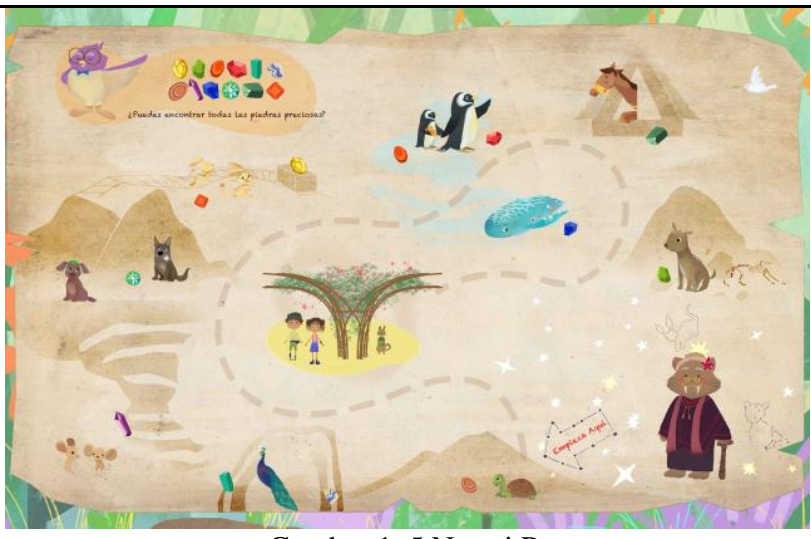

Gambar 1. 5 Narasi Ruang

[Sumber:https://designmattersatartcenter.org/proj/coanique m-safe-ninos-co-creating/gallery/ ]

5) Pintu masuk dibuat dengan tema pergunungan .Andes dengan tujuan untuk mengurangi rasa takut dan khawatir anak - anak.

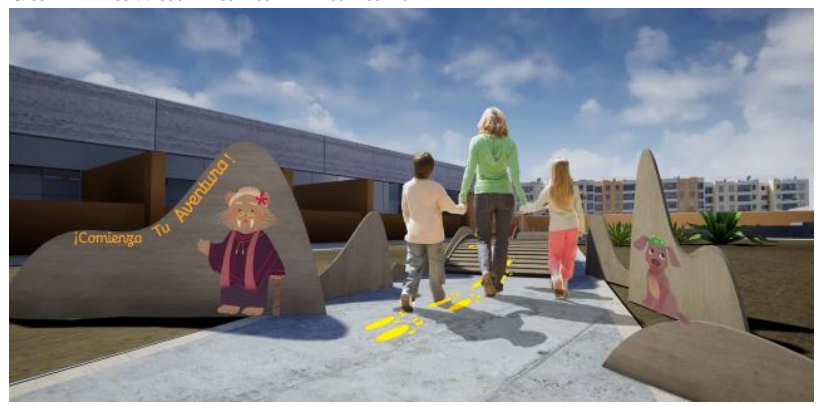

Gambar 1. 6 Pintu Masuk Bertema Pegunungan Andes

[Sumber:https://designmattersatartcenter.org/proj/coanique m-safe-ninos-co-creating/gallery/ ]

Berdasarkan contoh proyek desain social diatas, dapat dipelajari beberapa hal:

1) Budaya lokal komunitas dapat menjadi inspirasi proses desain

2) Solusi dapat berupa arsitektural, desain interior, desain produk dan desain komunikasi visual. Semua solusi ini harus bersinergi satu sama lain membentuk tema yang menyatu dan mendukung visi besar.

3) Mendengar dan mendesain bersama komunitas adalah hal penting bila ingin membuat solusi proyek desain sosial yang berkelanjutan, karena pada akhirnya tim desainer akan meninggalkan komunitas tersebut, jadi sang komunitas lah yang harus menghidupi solusi ini, jadi mereka harus dilibatkan di seluruh proses desain.

Komunitas yang menjadi bagian dari proyek ini adalah komunitas menganyam di
Rancabuaya, Tigaraksa, Tangerang sekitar $21 \mathrm{~km}$ dari Universitas Pelita Harapan menggunakan mobil. Pada awalnya, komunitas ini terbentuk dari seorang pengrajin anyaman, Bapak Rofi, yang termotivasi untuk membuka usahanya sendiri sehingga Beliau memutuskan untuk mengundurkan diri dari pabrik tempat Ia bekerja dan memulai karirnya sebagai pengusaha. Pak Rofi membagikan pengetahuannya kepada warga lain di desa Rancabuaya sehingga terbentuklah suatu komunitas yang dibantu oleh sebuah PSI (Profesional Sinergi Indonesia), sebuah organisasi non-pemerintah yang sudah berkontribusi di bidang pendidikan dan pertanian.

PSI atau Yayasan PSI (Profesional Sinergi Indonesia) adalah organisasi non-pemerintah yang terbentuk dengan tujuan untuk mengajak para kaum profesional dari segala bidang dengan niat untuk melayani masyarakat khususnya di daerah-daerah yang tertinggal. Visi PSI adalah kaum profesional ikut terlibat dalam pelayanan untuk mengembangkan daerah tertinggal dan kaum marjinal. Misi PSI adalah memobilisasi kaum profesional ikut dan terlibat dalam pencapaian visi. Keterlibatan Yayasan PSI di daerah Rancabuaya dimulai sejak tahun 2013. Pelayanan bisa dibagi menjadi 3 divisi: Divisi Kesehatan, Divisi Pemberdayaan Masyarakat, dan Divisi Pendidikan. Di desa Rancabuaya, PSI telah berkontribusi di bidang pemberdayaan masyarakat dan pendidikan. Yayasan PSI memberdaya masyarakat di bidang pertanian dan ekonomi yang dimulai sejak 2013 sampai sekarang. Kontribusi awal merupakan pertanian cabai yang dilakukan oleh satu keluarga. Kontribusi kedua adalah membagikan pohon rambutan ke penduduk desa. Dari kontribusi ini sebuah komunitas tani terbentuk di tahun 2018 dan melakukan penanaman 1000 tanaman hias dendrum. Di bidang Pendidikan, Yayasan PSI mengadakan program Bimbingan Belajar dan Rumah Baca dengan tujuan untuk meningkatkan kesadaran pentingnya Pendidikan bagi anak-anak dan orangtua. Program Pendidikan ini sudah diadakan di desa Rancabuaya sejak tahun 2014 sampai sekarang dengan kerjasama mahasiswa dari universitas lain seperti dari Untirta dan jurusan Teacher's College, UPH, dan alumni dari universitas lain.

Perwakilan NGO (Non-Government Organization) disini berperan sebagai katalis perubahan tindakan-tindakan warga di desa ini 
supaya bisa lebih maju dalam aspek ekonomis, sosial dan sebagainya. Di sini perwakilan NGO memberikan data dengan perspektif pengamat tentang masalah yang dialami sistem yang bekerja serta relasi tiap warga yang berperan di sistem ini. Aspirasi mereka untuk kedepannya adalah agar produk-produk bambu dan rotan mereka dipasarkan lebih luas lagi di mana mereka lebih bisa bersaing dengan produk buatan pabrik. Mereka berharap warga setempat lebih tertarik lagi dengan aktivitas menganyam ini supaya bukan hanya mereka yang bisa dapat penghasilan tetapi juga komunitas ini meningkat di dalam segi ekonomi.

Tujuan dari proyek desain sosial ini adalah untuk membantu proses mendapatkan ide untuk mengembangkan produk-produk baru. Ini bisa memberikan mereka keberanian untuk menjual produk mereka tanpa harus menunggu pesanan dari klien dengan proses yang efisien. Ketika hal ini sudah tercapai, kultur menganyam bisa ditingkatkan nilainya di Desa Jambe ini.

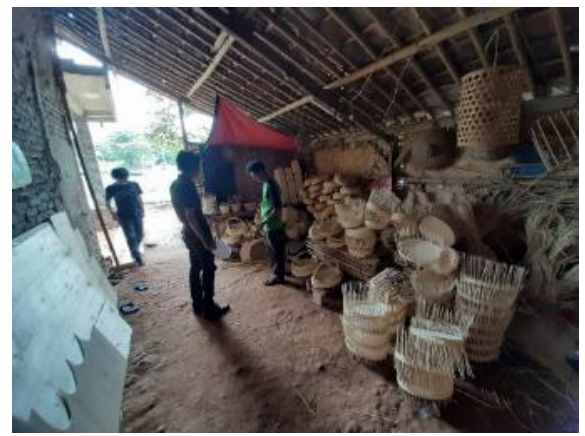

Gambar 1.9 Tempat Kerja Pengrajin [Sumber: Dokumentasi Penulis, 2020]

Di dalam desa Rancabuaya, komunitas bambu dan rotan ini memiliki banyak pengrajin. Di dalam kunjungan tim penulis, penulis bertemu dengan 2 (dua) pengrajin, Pak Rofi dan Pak Fendi. Mereka bekerja ketika ada pesanan. Pesanan ini biasanya lebih banyak pada saat hari raya atau menjelang pernikahan. Untuk penjualan produk mereka, mereka menggunakan B2B (Business to Business) dan lebih banyak ke B2C (Business to Customer) karena lebih banyak order langsung ke kedua pengrajin ini. Permasalahan yang dialami yang dihadapi komunitas saat ini adalah dari segi desain, pemasaran, dan produksi.

METODE

Ada berbagai jenis pemikiran desain dan jenis yang digunakan dalam penelitian ini adalah Pemikiran Desain yang berasal dari Stanford University yang terdiri dari lima tahap mulai dari berempati (emphatize), mendefinisikan masalah (define), pencarian ide (ideate), pembuatan purwarupa (prototype) dan tes. Siklus ini terbukti sebagai cara tercepat untuk mendapatkan hasil desain yang inovatif (Plattner, 2012). Tim Brown CEO IDEO salah satu pakar dalam pemikiran desain mendefinisikan pemikiran desain sebagai metode berpikir yang menggunakan rasa desainer dan kemampuan untuk mencocokkan kebutuhan manusia dengan teknologi dan strategi bisnis yang realistis. Tiga kombinasi faktor ini menghasillkan solusi desain yang bernilai dan memiliki peluang pasar (Brown, 2008). Inti dari pemikiran desain adalah desain yang berpusat pada manusia (human centered design).

Desain yang berpusat manusia dibangun di atas dasar empati kebutuhan manusia dengan menggunakan visualisasi dan model nyata untuk memecahkan masalah yang sulit. Setelah masalah telah didefinisikan, proses dapat kembali ke tahap berempati untuk memastikan masalah yang sudah didefinisikan adalah kendala utama yang pengguna rasakan dan harapkan. Langkah selanjutnya adalah tahap pencarian ide dapat lompat langsung ke tahap tes atau melalui proses pembuatan purwarupa (prototyping). Ide dan purwarupa yang sudah diuji keduanya harus kembali lagi ke proses pengembangan ide. Tujuannya adalah untuk mendapatkan umpan balik pengguna sedini. Proses perbaikan yang dilakukan terus-menerus dengan harapan di akhir proses ditemukan desain terbaik yang benar-benar memecahkan masalah.

Alur proses pemikiran desain yang digunakan di proyek desain sosial yang dikerjakan di paper ini. 


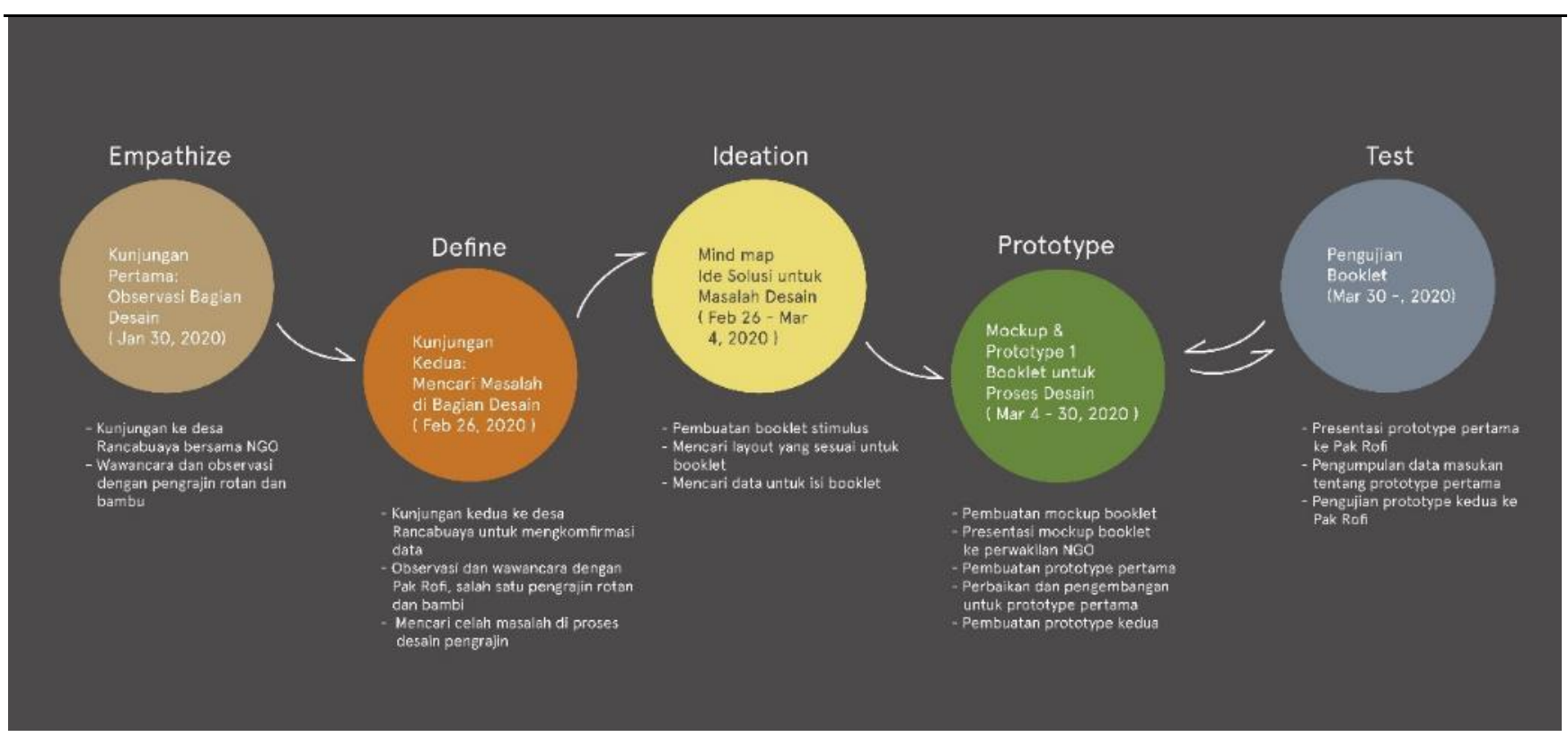

\section{HASIL}

\section{Emphatize}

Kunjungan ke desa Rancabuaya dilakukan untuk melakukan observasi tempat kerja pengrajin tersebut serta wawancara dengan pengrajin dan pihak NGO yang ditugaskan di sana. Kedua cara ini memiliki peran untuk lebih mengetahui usaha mereka dan sistem mereka yang sudah mereka jalani dan gambaran besar tentang masalah yang mereka alami. Wawancara dilakukan dengan dua pengrajin di Desa Jambe: Pak Rofi dan Pak Fendi. Berdasarkan hasil wawancara, bisa disimpulkan bahwa ada perbedaan dan persamaan antara kedua pengrajin rotan dan bambu di dalam proses mendesain produk-produk mereka:

Pak Rofi memiliki pemahaman mengenai material yang lebih luas dan pengalaman di bidang menganyam yang lebih lama dibandingkan dengan Pak Fendi sehingga ide maupun produk yang dihasilkan Pak Rofi lebih bervariatif dari segi teknik dan desain.

1) Pak Rofi menggunakan waktu luang untuk melakukan eksplorasi bahan dan anyaman jadi sedangkan Pak Fendi juga melakukan eksplorasi namun barang yang dihasilkan kurang bervariasi

2) Pak Rofi mendapatkan ide desain dari percobaan sedangkan Pak Fendi memiliki kendala di ide karena kurangnya pengalaman. Kurangnya pengalaman karena Pak Fendi sedikit melakukan percobaan sendiri

3) Kriteria keindahan desain produk dinilai dari teknisnya menurut Pak Rofi sedangkan Pak Fendi lebih menyesuaikan contoh yang diberikan.

4) Sebagian besar desain produk kedua pengrajin berdasarkan dari permintaan klien

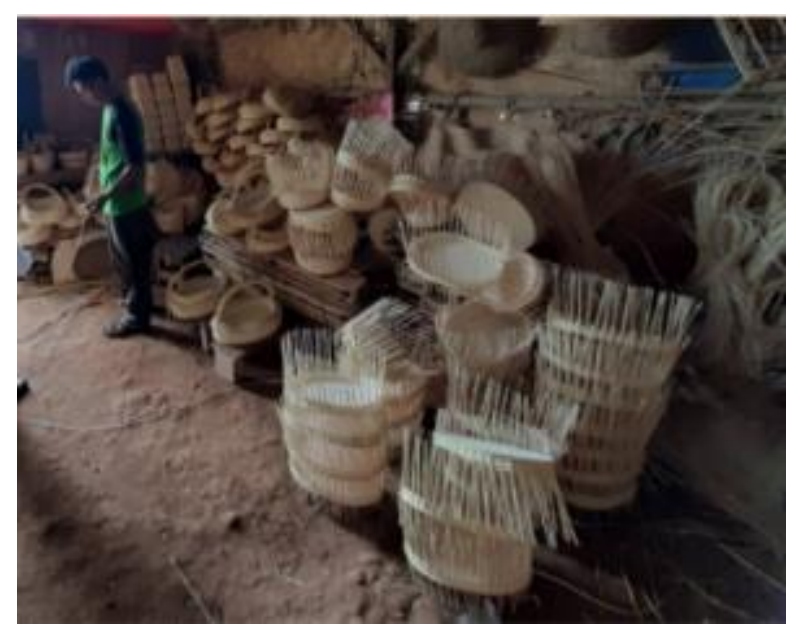

Observasi tempat kerja juga dilakukan dimana pengrajin menunjukkan produk-produk yang dihasilkan dan cara dia membuat produk-produk tersebut. Dari observasi, dirangkum kondisi di tempat kerja pengrajin dengan berikut:

1) Semua produk yang dihasilkan dengan tangan

Teknologi Tepat Guna 
2) Sebagian besar koleksi produk yang ditawarkan adalah wadah untuk menaruh barang

3) Pengrajin tidak memiliki gudang tersendiri untuk menyimpan barang

4) Keadaan ketika kunjungan selalu sepi, dan tidak ada kegiatan menganyam.

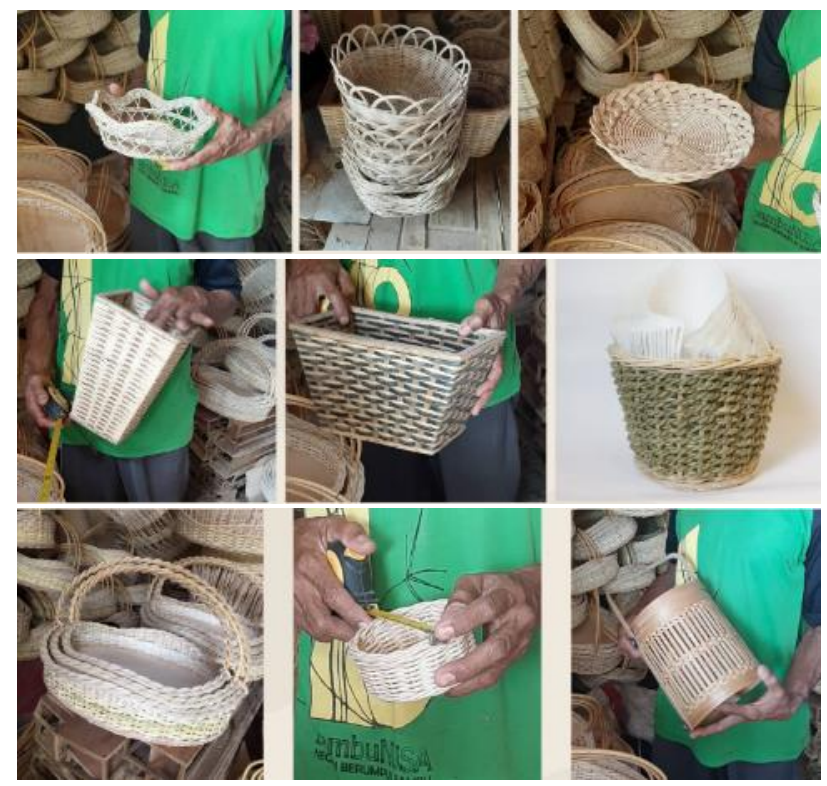

Gambar 1. 7 Produk Anyaman Pak Rofi [Sumber : Data Penulis, 2020]

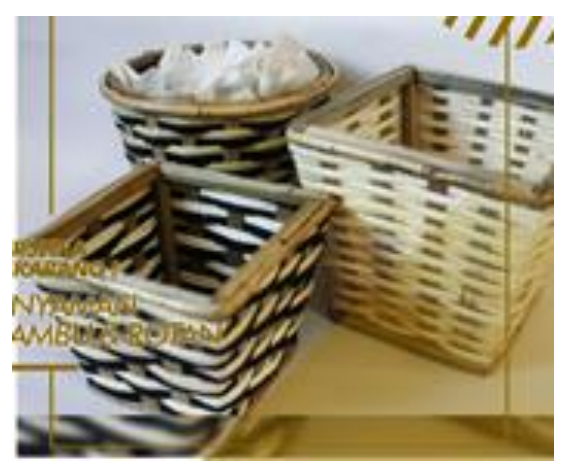

Gambar 1. 8 Produk Anyaman Pak Fendi [Sumber : Data Penulis, 2020]

Berdasarkan hasil data bisa disimpulkan bahwa kedua pengrajin, Pak Rofi dan Pak Fendi memiliki pendekatan desain yang berbeda. Pak Rofi adalah salah satu yang pertama untuk memutuskan untuk menjadi pengrajin dan ingin membagi pengetahuannya ke desanya, maka dapat dikatakan pengalaman Pak Rofi lebih banyak dari Pak Fendi.
Walaupun ada perbedaan pengalaman, kedua pengrajin tersebut memiliki masalah yang mirip yaitu sulitnya untuk mengembangkan ide produk baru. Hal ini bisa ditunjukkan dari koleksi produk yang kedua pengrajin itu miliki yang kebanyakan adalah wadah untuk membawa sesuatu.

\section{Define}

Untuk mendefinisikan masalah secara jelas, diawali dengan identifikasi proses untuk mengetahui dan menjelaskan semua aktivitas yang terjadi. Proses awal yang perlu di identifikasi adalah proses pengrajin dari mendapatkan bahan mentahnya menjadi produk bambu-rotan siap kirim ke klien. Tim penulis mengidentifikasi masalah-masalah yang dialami di dalam diagram proses ini. Setelah mengidentifikasi masalah, kunjungan kedua dilaksanakan untuk melakukan wawancara pengrajin untuk menanyakan pertanyaan tentang proses mereka lebih dalam lagi serta memvalidasi beberapa asumsi atau data sesuai dengan wawancara kunjungan pertama. Kendala yang dialami pengrajin di dalam aspek proses desain adalah kurangnya variasi dari sisi teknis dan konstruksi dari produk yang ditawarkan. Berikut adalah penjabaran masalah yang dialami kedua pengrajin tersebut:

Tabel 1. Identifikasi Masalah

\begin{tabular}{|c|c|c|c|}
\hline $\begin{array}{l}\text { Elemen di } \\
\text { Proses } \\
\text { Desain } \\
\end{array}$ & Pak Rofi & Pak Fendi & $\begin{array}{l}\text { Identifikasi } \\
\text { Masalah }\end{array}$ \\
\hline Bentuk/Pola & $\begin{array}{l}\text { Berdasarkan } \\
\text { dari percobaan } \\
\text { sendiri } \\
\text { Sering } \\
\text { bereksplorasi } \\
\text { dengan } 3 \text { bahan } \\
\text { yaitu bambu - } \\
\text { rotan - eceng } \\
\text { gondok } \\
\text { Kebanyakan } \\
\text { produk yang } \\
\text { diproduksi } \\
\text { adalah wadah } \\
\text { untuk } \\
\text { menaruh } \\
\text { sesuatu }\end{array}$ & $\begin{array}{l}\text { Berdasarkan } \\
\text { dari percobaan } \\
\text { namun kurang } \\
\text { bervariatif } \\
\text { Mempunyai } \\
\text { kecenderungan } \\
\text { untuk } \\
\text { mengikuti } \\
\text { contoh yang } \\
\text { sudah } \\
\text { diberikan } \\
\text { Kurang mampu } \\
\text { untuk } \\
\text { menemukan } \\
\text { bentuk atau } \\
\text { anyamannya } \\
\text { Produk yang } \\
\text { dihasilkan } \\
\text { kebanyakan } \\
\text { bentuk vas }\end{array}$ & $\begin{array}{l}\text { Bentuk produk } \\
\text { yang dihasilkan } \\
\text { kurang } \\
\text { bervariasi } \\
\text { Keterbatasan } \\
\text { dalam variasi } \\
\text { pola karena } \\
\text { menggunakan } \\
\text { pengetahuan } \\
\text { sendiri }\end{array}$ \\
\hline
\end{tabular}




\begin{tabular}{|c|c|c|c|}
\hline & & bunga & \\
\hline Ide Desain & $\begin{array}{l}\text { Lebih banyak } \\
\text { ide karena } \\
\text { pengalaman } \\
\text { yang cukup } \\
\text { lama namun } \\
\text { difokuskan ke } \\
\text { pola } \\
\text { Proses desain } \\
\text { Ketika ada } \\
\text { pemesanan } \\
\text { adalah dari } \\
\text { klien sendiri } \\
\text { Ketika ada } \\
\text { revisi dari } \\
\text { klien, kurang } \\
\text { bisa untuk } \\
\text { menanggapi } \\
\text { atau mengubah } \\
\text { ulang }\end{array}$ & $\begin{array}{l}\text { Proses desain } \\
\text { sepenuhnya dari } \\
\text { klien } \\
\text { Harus } \\
\text { mempelajari } \\
\text { anyaman } \\
\text { terlebih dahulu } \\
\text { Ketika } \\
\text { permintaan } \\
\text { klien } \\
\text { menggunakan } \\
\text { anyaman yang } \\
\text { berbeda } \\
\text { Kekurangan } \\
\text { ide karena } \\
\text { kurang } \\
\text { pengalaman dan } \\
\text { bereksplorasi di } \\
\text { bahan yang } \\
\text { digunakan }\end{array}$ & $\begin{array}{l}\text { Kekurangan } \\
\text { ide desain } \\
\text { Terlalu } \\
\text { bergantung } \\
\text { dengan ide } \\
\text { klien } \\
\text { Kekurangan } \\
\text { rangsangan } \\
\text { untuk mencoba } \\
\text { ide atau } \\
\text { anyaman baru }\end{array}$ \\
\hline Keindahan & $\begin{array}{l}\text { Penilaian } \\
\text { pengetahuan } \\
\text { sendiri yaitu } \\
\text { lebih dominan } \\
\text { ke penilaian } \\
\text { anyamannya }\end{array}$ & $\begin{array}{l}\text { Penilaian } \\
\text { berdasarkan } \\
\text { contoh referensi } \\
\text { dan klien }\end{array}$ & $\begin{array}{l}\text { Lebih fokus ke } \\
\text { teknik anyaman } \\
\text { sebagai aspek } \\
\text { keindahan dari } \\
\text { pada } \\
\text { keseluruhan } \\
\text { produk tersebut }\end{array}$ \\
\hline
\end{tabular}

[Sumber : Data Penulis, 2020]

Dari data yang didapat dari komunitas tersebut, ada tiga tema masalah yang mempengaruhi permasalahan mereka.

\section{1) Kesulitan untuk mendapatkan ide baru}

Pengrajin sering melakukan eksplorasi bahan di waktu luang mereka, mereka mengembangkan produk baru yang terlalu mirip dengan produk sebelumnya. Berdasarkan hasil wawancara pengrajin mengatakan kesulitan ketika diminta klien pengrajin yaitu toko bunga di Rawa Belong untuk mengembangkan produk baru

\section{2) Harus menunggu pesanan}

Karena tidak bisa menawarkan produk baru pada klien, maka pengrajin harus menunggu order dan desain dari klien

\section{3) Sulit menentukan spesifikasi karena tidak adanya sample dan banyaknya varian}

Pengrajin tidak memiliki sample pola anyaman dan variasi produk yang selama ini sudah dibuat. Hal ini yang juga menyebabkan pengrajin tidak bisa menawarkan desain bar uke klien.
Berdasarkan analisa diatas maka proyek desain sosial difokuskan untuk mendesain buku yang dapat menjadi alat bantu bagi pengrajin untuk mengembangkan produk dan pola anyaman yang baru.

\section{Ideate}

Proses pencarian ide diawali dengan penentuan konsep produk, sbb:

Produk yang dirancang adalah sebuah buku pengembangan anyaman bambu, rotan, jenis finishing, serta instruksi untuk menganyam polapola anyaman. Buku ini untuk menstimulasi terbentuknya ide-ide desain baru. Buku ini ditujukan untuk Pengrajin bambu dan rotan di Rancabuaya di Desa Jambe, Tigaraksa, Tangerang. Buku ini dapat digunakan ketika para pengrajin ingin membuat pola anyaman baru, dan ide produk baru. Buku ini dibutuhkan karena adanya kendala pengrajin untuk mengembangkan produk baru, sehingga pengrajin hanya bisa menunggu order dari klien, tidak bisa menawarkan produk baru. Dengan buku ini diharapkan pengrajin dapat berkreasi pola anyaman dan finishing yang belum pernah terpikirkan sebelumnya.

Tema desain buku diambil untuk memberikan arah desain terhadap pembuatan buku Pengembangan Desain Rotan dan Bambu. Kata kunci yang pertama adalah technical, yang berarti buku stimulus yang memiliki informasi teknis menyeluruh tentang tipe anyaman yang digunakan dari nama sampai harga dan jenis finishing yang tersedia. Kata kunci kedua adalah organized, karena buku ini harus terorganisir dengan baik supaya pengrajin bisa mengakses kombinasi pilihan dengan cepat dan mudah. Kata kunci yang terakhir adalah humble, karena buku ini harus disusun sederhana mungkin agar dapat dipahami dengan mudah oleh pengrajin. 


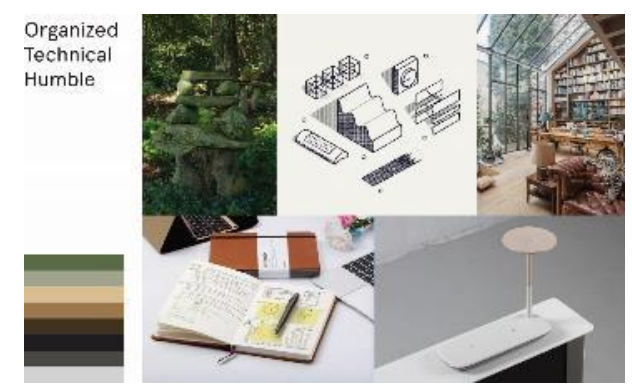

Gambar 1. 9 Moodboard Tema

[Sumber : Data Penulis, 2020]

\section{Prototype}

Alur proses perkembangan ide desain

\begin{tabular}{|c|c|c|c|c|c|}
\hline Ideasi tahap 5 & Feedback pengguna 1 & Ideasi tahap 2 & Ideasi tahap 3 & Ideasi tahap 4 & Prototype 1 \\
\hline 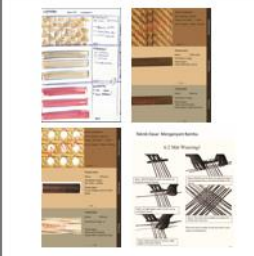 & & $\begin{array}{ll}\text { BukuVariasi } \\
\text { Rotan }\end{array}$ & 64 & $\begin{array}{l}\text { Buku } \\
\text { Pengembangan } \\
\text { Desain } \\
\text { Anyzanan } \\
\text { Bambu }\end{array}$ & $\frac{1}{2+20}$ \\
\hline $\begin{array}{l}\text { Gambaran awal mengenai isi } \\
\text { dari buku ditetapkan. Buku ini } \\
\text { akan terdiri dari } 3 \text { bagian: } \\
\text { Bagian anyaman, warna, } \\
\text { finishing, serta pengetahuan } \\
\text { untuk pengembanganteknik } \\
\text { anyam }\end{array}$ & $\begin{array}{l}\text { Input dari PSI: bagian } \\
\text { finising tidak } \\
\text { diperlukan, ide berupa } \\
\text { buku sudah cukup baik, } \\
\text { Kode SKU harus } \\
\text { dimasukkan ke dalam } \\
\text { buku }\end{array}$ & $\begin{array}{l}\text { Penetapan “ } \\
\text { - } \text { spesifikasi kertas } \\
\text { berukuran } \mathrm{A} 5(210 \mathrm{~mm} \\
\times 148 \mathrm{~mm}) \\
\text { - Variasi dan Isi buku } \\
\text { anyaman } \\
\text { - Pendataan jenis } \\
\text { anyaman pengrajin }\end{array}$ & $\begin{array}{l}\text { Dummy } 1 \text { buku anyaman } \\
\text { Kendala: } \\
\text { Sample anyaman terlalu besar } \\
\text { sehingga sulitmasuk dalam } \\
\text { buku } \\
\text { Solusi } \\
\text { Ukuran buku diperbesar } \\
\text { menjadi A4 agar sesuai dengan } \\
\text { proporsi sample anyaman }\end{array}$ & $\begin{array}{l}\text { Penambahan fitur moodboard } \\
\text { untuk pengembangan ide } \\
\text { pengrajin } \\
\text { Fitur sample anyaman yang dapat } \\
\text { dicopot pasang, sehingga } \\
\text { pengrajin dapat mix and match } \\
\text { dengan mudah } \\
\text { Dummy buku } 2 \text { berukuran A4 } \\
\text { Revisi judul buku Pengembangan } \\
\text { desain anyaman }\end{array}$ & $\begin{array}{l}\text { Pembuatan prototipe } \\
\text { dengan bahan art carton } \\
260 \mathrm{gr} / \mathrm{m}^{2}\end{array}$ \\
\hline
\end{tabular}

\section{Deskripsi Penggunaan Produk}

Hal yang perlu ditekankan adalah, buku ini berfungsi sebagai alat bantu untuk membantu menentukan spesifikasi produk yang diinginkan, sehingga banyak menekankan pada mix and match (cocok-pasang).

\section{Pemilihan bahan anyaman}

Pada awalnya, pengrajin menggunakan buku yang sesuai dengan bahan yang digunakan, yaitu bambu, rotan, atau bahkan kombinasi kedua material ini.
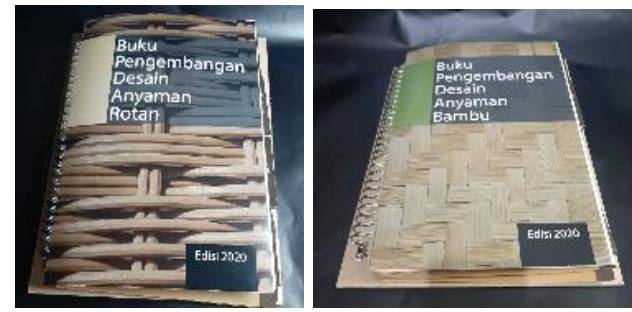

Gambar 1. 10 Buku Pengembangan Desain Anyaman Rotan dan Bambu

[Sumber : Data Penulis, 2020]

\section{Pemilihan Spesifikasi Produk}

Tahap selanjutnya adalah pemilihan spesifikasi produk. Terdapat 4 bagian dari spesifikasi produk yang dapat dikombinasikan : alas, dinding, tepi, dan warna.

Alas

Pada bagian paling atas, yaitu bagian untuk alas, pengrajin ataupun konsumen memilih bahan ataupun jenis anyaman yang digunakan untuk bagian alas atau dasar atau bawah dari produk anyaman.

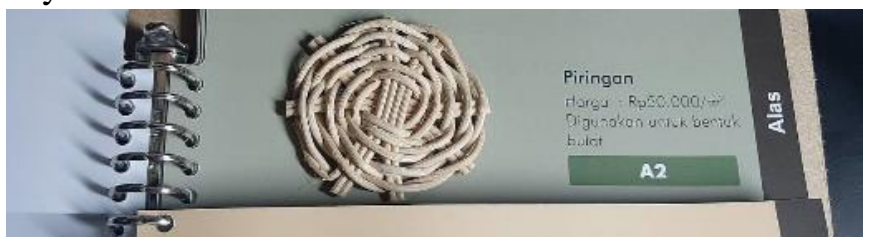

Gambar 1. 11 Bagian Alas dari isi buku

[Sumber : Data Penulis, 2020]

\section{Dinding}

Bagian dinding adalah bagian samping dari produk nantinya. Pengrajin atau konsumen memilih jenis anyaman apa yang mau diterapkan pada produk nantinya. Pada umumnya, bagian dinding inilah 
yang sering dilakukan kombinasi material. Oleh karena itu, untuk melakukan kombinasi, dapat dilakukan dengan cara melepas bagian contoh anyaman yang ingin dikombinasi dari buku lain, lalu menyandingkannya dengan buku ini, agar dapat terlihat kombinasinya. (Gambar 3.37).

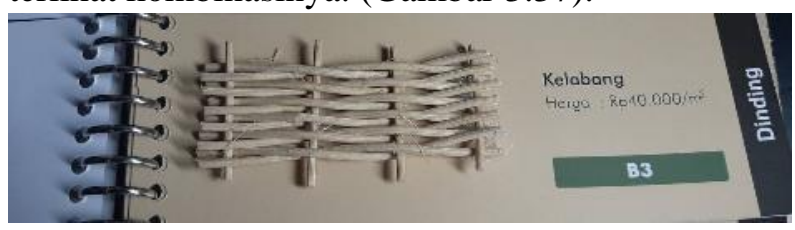

Gambar 1. 12 Bagian Dinding dari isi buku [Sumber : Data Penulis, 2020]

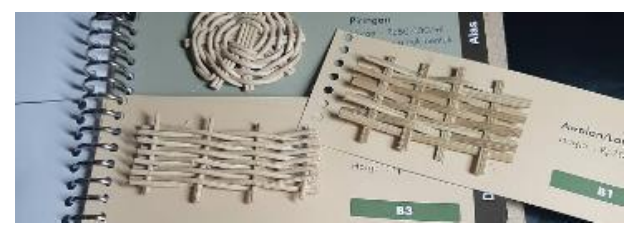

Gambar 1. 13 Bagian Dinding Dari Isi Buku Kombinasi Rotan Dan Bambu

[Sumber : Data Penulis, 2020]

\section{Tepi}

Setelah itu, pengrajin ataupun konsumen memilih bagian tepian dari produk akhir. Bagian tepian adalah bagian ujung dari anyaman. Misalnya untuk piring, tepi piring adalah sisi terluar dari piring. Sedangkan tepi keranjang adalah bibir keranjang itu sendiri.

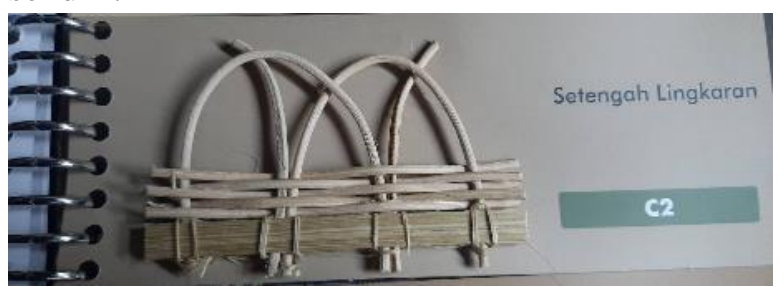

Gambar 1. 14 Bagian tepi dari isi buku

[Sumber : Data Penulis, 2020]

\section{Warna}

Kemudian, pengrajin ataupun konsumen memilih warna yang diinginkan.

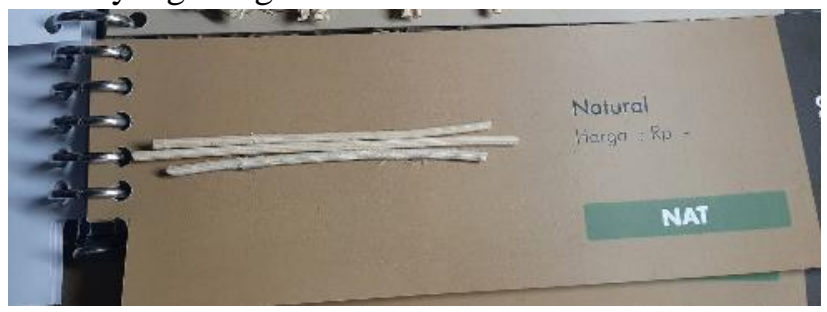

Gambar 1. 15 Bagian Warna dari isi buku

[Sumber : Data Penulis, 2020]

Tahapan untuk pemilihan spesifikasi produk tidak harus dilakukan secara berurutan. Namun yang penting adalah agar semua spesifikasi produk ditentukan, agar dapat terlihat perbandingannya.

\section{PEMBAHASAN}

Pada bagian pembahasan, penulis akan membandingkan dan menghubungkan kembali masalah yang muncul pada saat perancangan anyaman, dengan solusi yang sudah dibuat, yaitu Buku Pengembangan Desain Anyaman Rotan dan Bambu.

\section{Tabel 4.1 Pembahasan Tercapainya Solusi} yang Dibuat

\begin{tabular}{|c|c|c|}
\hline $\begin{array}{c}\text { Permasalahan } \\
\text { dan Aspirasi } \\
\text { Komunitas }\end{array}$ & $\begin{array}{l}\text { Solusi yang } \\
\text { diajukan }\end{array}$ & Indikator pencapaian \\
\hline $\begin{array}{l}\text { Kesulitan untuk } \\
\text { mendapatkan ide } \\
\text { baru }\end{array}$ & $\begin{array}{l}\text { Pembuatan Buku } \\
\text { referensi yang berisi } \\
\text { inventaris anyaman, } \\
\text { sehingga pengrajin } \\
\text { dapat menganalisa } \\
\text { dan mencoba untuk } \\
\text { bereksperimen }\end{array}$ & \multirow[t]{2}{*}{$\begin{array}{l}\text { Jumlah produk baru atau } \\
\text { anyaman baru. }\end{array}$} \\
\hline $\begin{array}{l}\text { Harus menunggu } \\
\text { pesanan }\end{array}$ & $\begin{array}{l}\text { Saat tidak ada } \\
\text { pesanan, dapat } \\
\text { berinovasi dengan } \\
\text { membuat produk } \\
\text { yang tersedia stoknya. } \\
\text { Dengan buku ini, } \\
\text { pengrajin dapat } \\
\text { bereksperimen, atau } \\
\text { bahkan } \\
\text { mengembangkan ilmu } \\
\text { menganyamnya }\end{array}$ & \\
\hline $\begin{array}{l}\text { Sulit menentukan } \\
\text { spesifikasi } \\
\text { karena tidak } \\
\text { adanya sample } \\
\text { dan banyaknya } \\
\text { varian }\end{array}$ & $\begin{array}{l}\text { Pembuatan buku yang } \\
\text { memiliki sample dari } \\
\text { anyaman dan } \\
\text { material, sehingga } \\
\text { memudahkan } \\
\text { konsumen untuk } \\
\text { menentukan } \\
\text { spesifikasi }\end{array}$ & $\begin{array}{l}\text { Komunikasi klien } \\
\text { meningkat karena } \\
\text { pengrajin dapat dengan } \\
\text { mudah menjelaskan } \\
\text { kepada klien mengenai } \\
\text { variasi anyaman dan } \\
\text { bahan yang dapat dipilih. }\end{array}$ \\
\hline
\end{tabular}

[Sumber : Data Penulis, 2020]

\section{KESIMPULAN}

Dibalik produksi produk anyaman yang berskala industri yang cukup besar, ternyata masih ada para pengrajin berskala kecil menengah (UKM) yang juga bersaing di pasar yang sama dengan para

Teknologi Tepat Guna 
produsen besar. Produsen berskala besar pastilah mempunyai tim produksi, desain, dan pemasaran untuk memperluas pasar dari produsen itu sendiri. Para pengrajin yang berskala UKM ini harus melakukan semuanya sendiri. Tim akademisi desain produk, memiliki tanggung jawab juga untuk mendorong UKM ini agar dapat terus bertahan dan mampu bersaing dengan produsen lainnya, dengan menggunakan apa yang telah dipelajari selama kuliah.

Selama proses perancangan ini terdapat beberapa kendala, seperti jauhnya desa Rancabuaya, kendala untuk berkomunikasi dengan pengrajin, komunikasi yang harus terus dijaga dengan tim desain dan tim produksi, serta pada saat proses perancangan muncul pandemik Covid-19 yang menghambat pergerakan tim akademisi. Namun kunci dari selesainya proses perancangan ini adalah komunikasi antar pengrajin, tim akademisi dan PSI.

Beberapa rekomendasi yang dapat dihasilkan dari studi ini bagaimana mengaplikasikan pemikiran desain dalam konteks desain sosial sbb:

1) Pada tahap empathize, pastikan studi terhubung dengan semua pemangku kepentingan yang berbeda melalui wawancara dan pengamatan. Dalam proyek ini stakeholder inti adalah dosen, mahasiswa, pengrajin dan pihak NGO.

2) Pada tahap define, pelu dilakukan analisis sebab dan akibat yang kuat untuk mengetahui akar penyebab masalah. Hal ini sangat penting untuk memastikan solusi desain memecahkan masalah penting dan mendesak.

3) Pada tahap ideation, utamakan kualitas atas kuantitas dan feedback dari stakeholder. Ide - ide harus sedini mungkin direview dan disetujui oleh para stakeholder inti.

4) Pada tahap pembuatan purwarupa (prototyping), diawali dengan pembuatan model atau disebut dengan dummy. Dummy harus dibuat dengan material aslinya sehingga semua konstruksi dan kendala teknis dapat dievaluasi sedini mungkin. Contohnya pada buku anyaman ini sebelumnya berukuran A5, tapi karena kendala teknis sampel anyaman yang cukup tebal maka ukuran buku diperbesar menjadi A4 dan menggunakan Art Carton 260gr/m2.

5) Pada tahap pengujian (test), menyampaikan ideide dengan bercerita sangat penting. Jadi, pengguna tahu proses dan kegiatan yang terjadi terkait dengan objek. Misalnya, ketika menjelaskan proses penggunaan buku ini tim menjelaskan dengan studi kasus bila pengrajin harus mengembangkan produk baru.

\section{UCAPAN TERIMAKASIH}

Penulis ingin mengucapkan terima kasih atas bantuan, bimbingan serta kerjasama dari berbagai pihak yang telah membantu dalam penyusunan karya ilmiah ini. Penulis menyampaikan terima kasih kepada :

1) Dr. Martin L. Katoppo S.T, M.T.selaku Dekan Fakultas Desain Universitas Pelita Harapan

2) Dr.-Ing. Ihan Martoyo, S.T., M.Sc selaku Ketua LPPM Universitas Pelita Harapan

3) Artikel ini merupakan bagian dari publikasi penelitian internal UPH dengan no. P-091-S-SOD/III/2020 dan terdaftar di LPPM UPH.

\section{REFERENSI}

Amatullo, M., Becerra, L., \& Montgomery, S. (2011). Designmatters Case Studies: Design Education Methodologies as a Tool for Social Innovation. In VentureWell. Proceedings of Open, the Annual Conference (p. 1). National Collegiate Inventors \& Innovators Alliance.

Armstrong, L., Bailey, J., Julier, G., \& Kimbell, L. (2014). Social design futures: HEI research and the AHRC.

Brown, T. (2008). Design thinking. Harvard business review, 86(6), 84 .

Jégou, F., \& Manzini, E. (2008). Collaborative services. Social innovation and design for sustainability (Vol. 1). Polidesign.

Margolin, V., \& Margolin, S. (2002). A "social model" of design: Issues of practice and research. Design issues, 18(4), 24-30.

Papanek, V., \& Fuller, R. B. (1972). Design for the real world (p. 22). London: Thames and Hudson. 
Plattner, H., Meinel, C., \& Leifer, L. (Eds.). (2012). Design thinking research. Berlin: Springer.

Ramirez, M. (2011). Designing with a social conscience: An emerging area in industrial design education and practice. In DS 68-5: Proceedings of the 18th International Conference on Engineering Design (ICED 11), Impacting Society through Engineering Design, Vol. 5: Design for X/Design to X, Lyngby/Copenhagen, Denmark, 15.-19.08. 2011.

Whiteley, N. (1993). Design for society. Reaktion books. 